Case Report

\title{
Primary Cutaneous Follicle Centre Lymphoma with Hodgkin and Reed-Sternberg Like Cells: A Case Report and Review of the Literature
}

\author{
Fatima A. Aldarweesh and Diana O. Treaba \\ Department of Pathology and Laboratory Medicine, Warren Alpert Medical School of Brown University, Rhode Island Hospital, \\ Providence, RI, USA \\ Correspondence should be addressed to Diana O. Treaba; dtreaba@lifespan.org
}

Received 20 June 2017; Accepted 20 August 2017; Published 26 September 2017

Academic Editor: Eduardo Arellano-Rodrigo

Copyright (c) 2017 Fatima A. Aldarweesh and Diana O. Treaba. This is an open access article distributed under the Creative Commons Attribution License, which permits unrestricted use, distribution, and reproduction in any medium, provided the original work is properly cited.

\begin{abstract}
An elderly woman with a complex medical history presented with a left forearm mass that slowly developed for several months. The excisional biopsy of this skin mass was remarkable for involvement by a follicle centre cell derived lymphoma with a nodular and diffuse pattern associated with a subset of scattered Hodgkin and Reed-Sternberg like cells. Fluorescence in situ hybridization studies did not detect the presence of IgH-bcl2 fusion transcript, and molecular studies were negative for immunoglobulin heavy chain gene rearrangements and EBV DNA sequences. Hodgkin and Reed-Sternberg like cells are rarely reported in FLs, and the association with primary cutaneous follicle centre lymphoma is extremely rarely seen. To our knowledge, our case is the second case of primary cutaneous follicle centre lymphoma with Hodgkin and Reed-Sternberg like cells.
\end{abstract}

\section{Introduction}

Follicular lymphoma comprises approximately $20 \%$ of all lymphomas in the United States and has a slight female predominance $[1,2]$. The most frequent sites of involvement are the lymph nodes, spleen, bone marrow, peripheral blood, and Waldeyer's ring with nonhematopoietic sites such as gastrointestinal tract, soft tissue, skin, ocular adnexa, breast, and testis being also involved, often in the context of systemic disease [2]. Skin involvement has been reported in approx. $4 \%$ of the cases $[3,4]$. Approximately $90 \%$ of follicular lymphoma (FL) cases are characterized by the presence of the $t(14 ; 18)$ (q32; q21). The small subset of $t(14 ; 18)$ negative FL is less well understood and seems to have distinct molecular features including bcl6 rearrangements and trisomy $3[1,5]$. Primary cutaneous follicle centre lymphoma (PCFCL) is a separate diagnostic entity in the WHO 2008 classification [6] and also in the 2016 WHO criteria revision [7] accounting for approximately $60 \%$ of the primary cutaneous B-cell lymphomas [6]. This lymphoma may occur as a solitary plaque or mass, especially involving the head or trunk area, may form a small group of closely located lesions, and rarely may be multifocal. While morphologically and immunophenotypically PCFCL has many similarities with the classic FL, generally they lack bcl2 expression with only a small number of cases being bcl2 positive by immunohistochemistry [8-12] but lacking the IgH-bcl2 fusion. Szablewski and coworkers studied 20 PCFCL cases using BOB1/bcl2 double immunostaining and interphase fluorescence in situ hybridization and concluded that a subset harbors similar genetic alterations with nodal FLs (NFL), including BCL2 breaks and 1p36 deletion [13]. Dissemination to extracutaneous sites occurs in approx. 10\% of these patients. Both classical Hodgkin lymphoma and nonHodgkin lymphomas have been reported in the same person and occasionally FLs have H/RS-like large cells, within the neoplastic nodules or at their periphery [14-21]. The finding of a $t(14 ; 18)$ in a cutaneous FL is a rare event and strongly suggests a secondary NFL.

We present a rare case of IgH-bcl2 negative FL with H/RS cells presenting as a solitary mass on the forearm of an 89year-old woman. The lack of bcl2-IgH fusion and the absence of lymphadenopathy favor a primary cutaneous follicle centre 


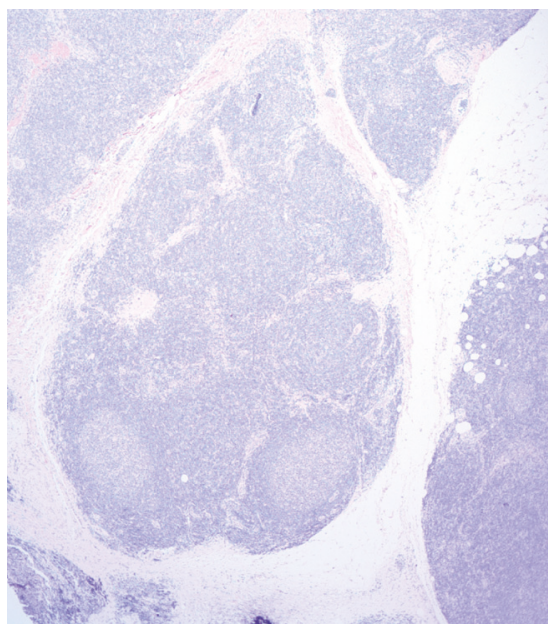

(a)

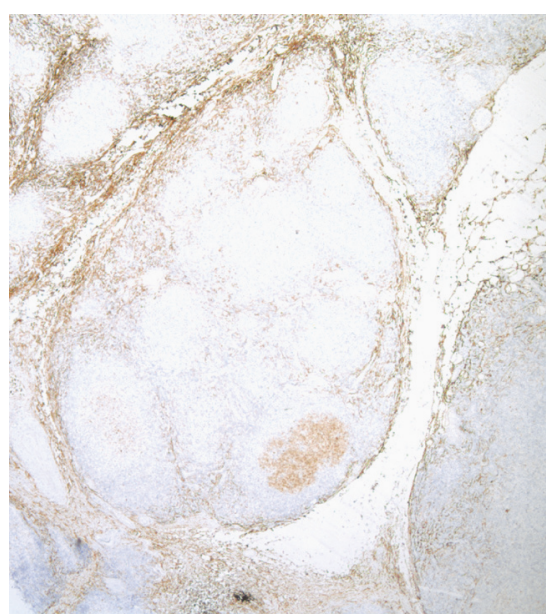

(d)

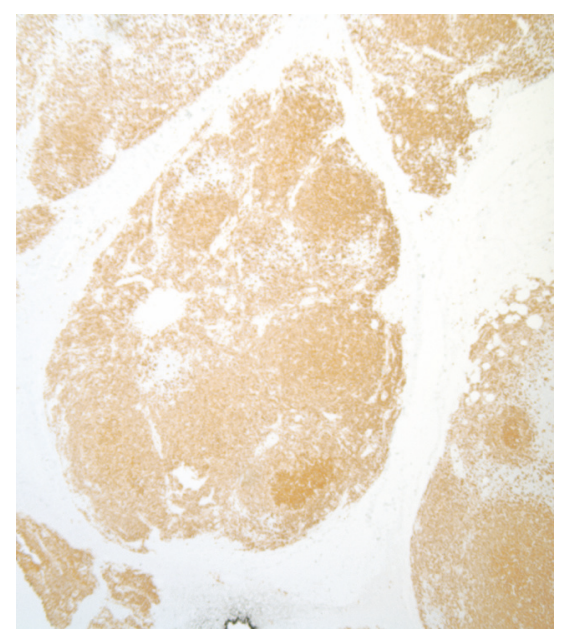

(b)

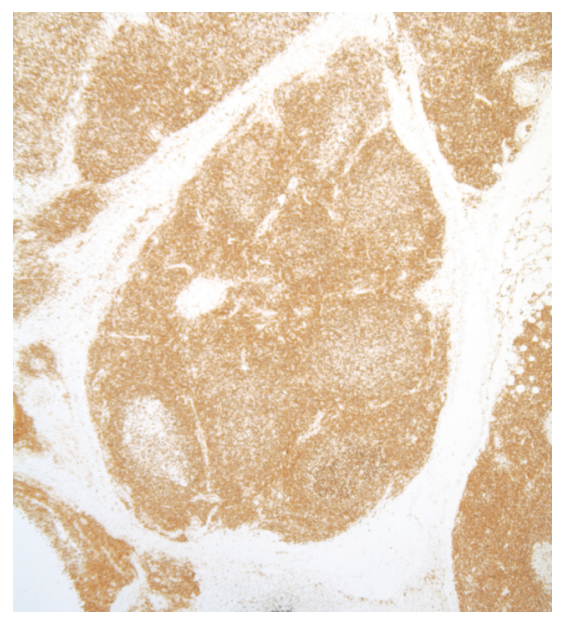

(e)

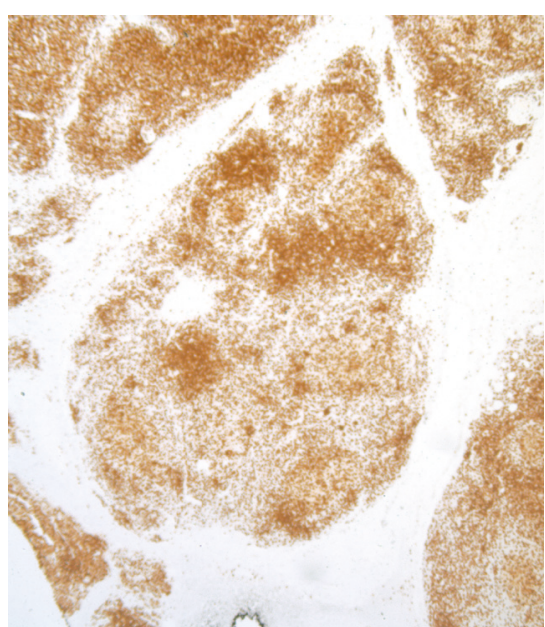

(c)

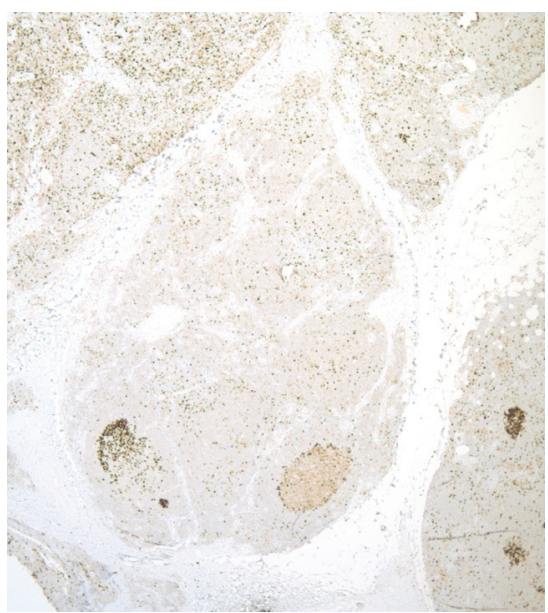

(f)

Figure 1: The neoplastic lymphoid follicles ((a), H\&E stain, 400x) are of B-cell lineage ((b), CD20 immunostain, 400x), are admixed with a subset of CD3 positive T-cells ((c), CD3 immunostain, 400x), coexpress CD10 ((d), CD10 immunostain, 400x) and bcl2 positivity ((e), bcl2 immunostain, 400x), and have proliferation rates of approximately 20-30\% ((f), MIB-1 immunostain, 400x).

lymphoma with H/RS cells, a very rare diagnostic entity reported only in one prior case in the English medical literature.

\section{Report of a Case}

An 89-year-old female with a past medical history significant for type 2 diabetes, hypertension, hypothyroidism, coronary artery disease, status after CABG, and hysterectomy presents with a left forearm mass that developed during several months. The patient did not have lymphadenopathy or Bsymptoms. The excised $3 \times 2.2 \times 2 \mathrm{~cm}$ mass is remarkable for a dense intradermal lymphoid population with a predominant diffuse pattern of infiltration in the upper dermis and a nodular/follicular pattern in the deeper regions sampled. Some lymphoid follicles had a monotonous appearance of their germinal centres, being composed predominately of centrocytes and only a few centroblasts and lacked tingible body macrophages. In the upper dermis, scattered large transformed lymphoid cells with a Hodgkin and ReedSternberg like morphology are identified. By immunohistochemistry, there are neoplastic B-lymphoid follicles coexpressing $\mathrm{CD} 20+, \mathrm{CD} 10+, \mathrm{bcl} 6+$, and bcl2+ (Figure 1) and exhibiting proliferation rates of approximately $20-30 \%$ (MIB1 antibody), centred by well-developed CD21+ follicular dendritic meshworks. In the upper dermis the H/RS-like cells are noted surrounded by a prominent $\mathrm{CD} 3+$, bcl2 + Tcell population. The H/RS-like cells are largely CD45+ and coexpress CD30, CD20, PAX5, bcl2 (Figure 2), CD79a, bcl6, and MUM1 positivity being negative for CD15. An antiEBV latent membrane protein antibody is negative. FISH studies were negative for IgH-bcl2 fusion. In addition, PCR studies were reported negative for immunoglobulin heavy chain gene rearrangements, T-cell receptor beta, and gamma gene rearrangements and also for EBV DNA sequences.

Given the localized disease, no other treatment was initiated. The patient was lost to follow-up. 


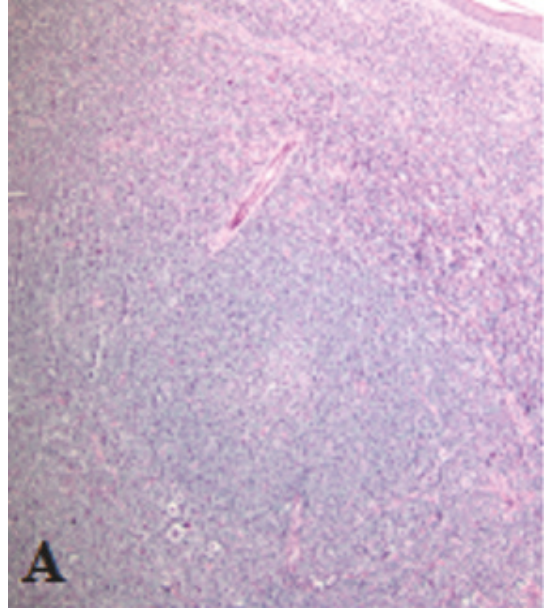

(a)

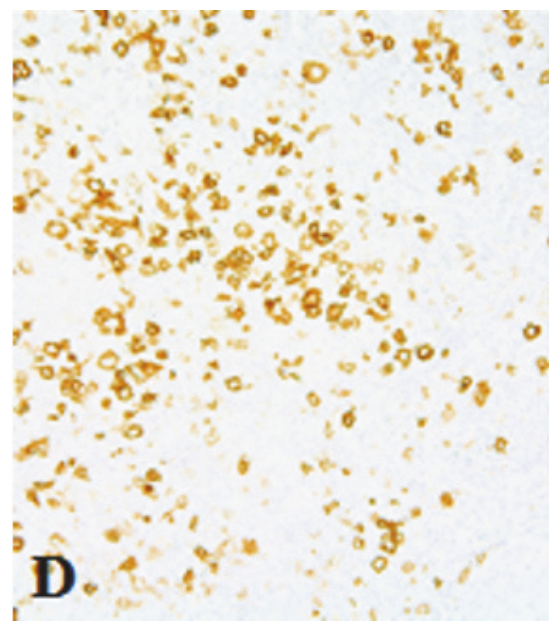

(d)

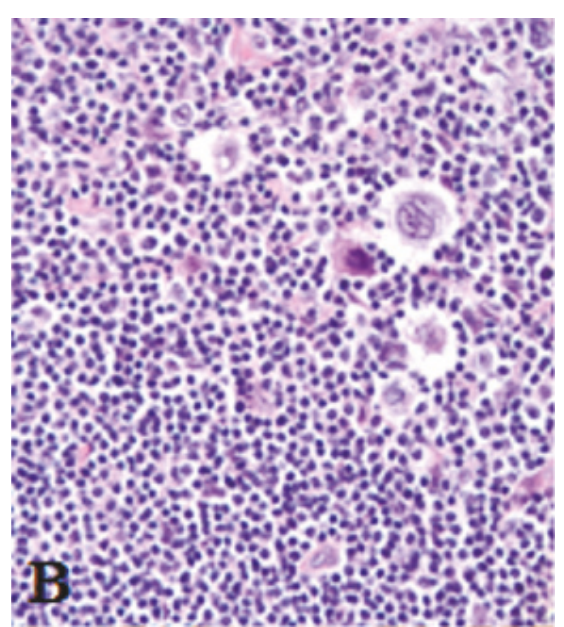

(b)

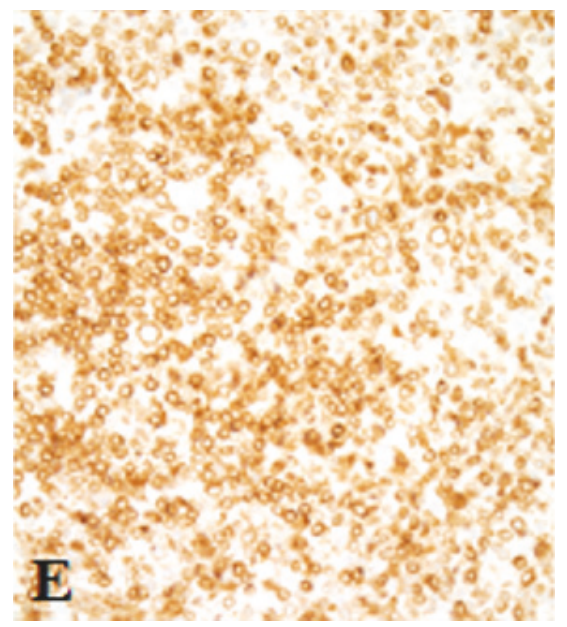

(e)

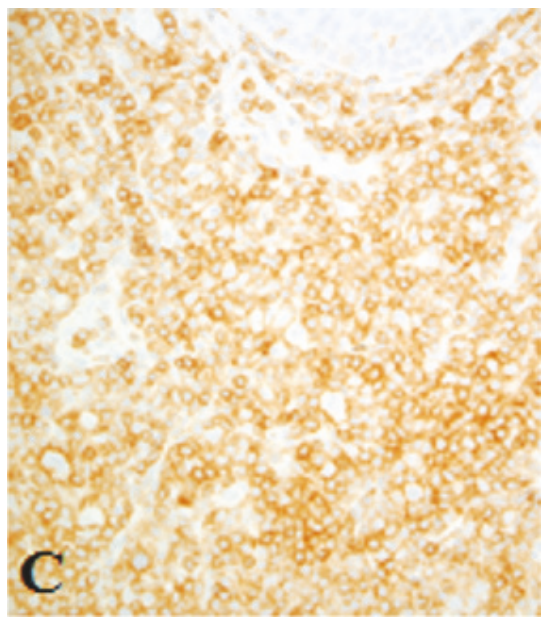

(c)

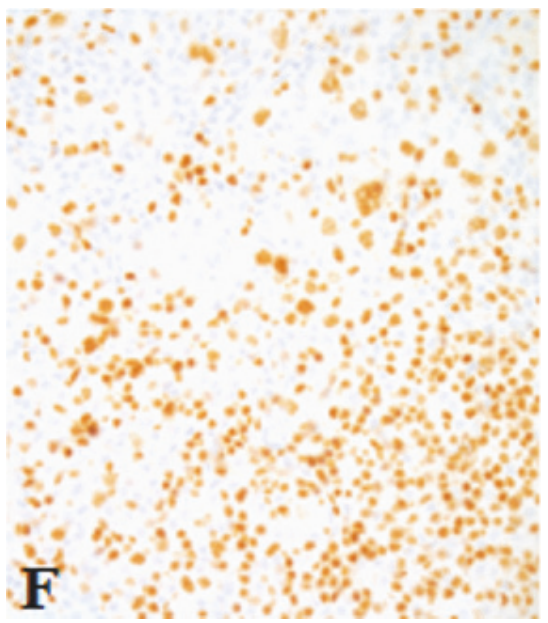

(f)

Figure 2: The upper dermis ((a), H\&E stain, 400x) has large transformed Hodgkin and Reed-Sternberg like cells ((b), H\&E stain, immersion oil 1000x) that coexpress CD45 ((c), CD45 immunostain, 400x), CD30 ((d), CD30 immunostain, 400x), and bcl2 positivity ((e), bcl2 immunostain, 400x) and are also PAX5 positive ((f), PAX5 immunostain, 400x).

\section{Discussion}

The unusual presentation of FLs with H/RS-like cells has been acknowledged in the medical literature mostly in case reports or in review studies and, thus, the true incidence of this association is still unknown. In addition, their presence may be significantly underreported, with the H/RS-like cells being counted as centroblasts in FLs. While their immunophenotype has generally variations from the classic (CD45-, CD30+, PAX5 weak+, and CD15 variably+) Hodgkin lymphoma immunophenotype [22-24], a common germinal centre origin has been suggested for both [22, 25]. In the majority of the reported FL cases their H/RS cells were CD30 positive and coexpressed B-cell markers (CD20, BOB1, PAX5, and OCT.2) and bcl6, were variably CD45 and bcl2 positive, and were less often CD15 or CD10 positive. Similar to classical Hodgkin lymphoma H/RS cells, they can be EBV positive [24]. Furthermore, in some cases of composite lymphomas (CHL and FLs) the H/RS cells of the CHL carried the same IgH-bcl 2 translocation as the associated FL, further suggesting a common cell of origin [25-27].

Primary cutaneous follicle centre lymphoma (PCFCL) is most often noted in middle aged to elderly patients, slightly more frequent in men, and has predilection for the head, neck, and the trunk regions, forming single or multiple lesions, papules, plaques, or nodules. Morphologically, PCFCL consists of centrocytes and centroblasts and infiltrates usually the lower half of the dermis and the subcutaneous regions with a follicular, follicular and diffuse, or a diffuse pattern. The immunophenotype is reminiscent of the classical FL with expression of bcl6 and variable CD10 positivity with only weak or completely lacking (in $70 \%$ of the cases) bcl 2 expression. The absence of bcl2 is also noted at a molecular level, with PCR studies of the PCFCL being virtually always $t(14 ; 18)$ negative. However, the presence of the $t(14 ; 18)$ has been occasionally reported by FISH analysis [28]. The lack of immunoglobulin heavy chain gene rearrangement detection by PCR as seen in our case is generally not unusual for 
low-grade FLs and often is attributed to an associated large amount of polytypic B-lymphoid cells present in the sample [29].

In our review of the medical literature we identified a single case of PCFCL case with numerous H/RS-like cells positive for CD30, CD15, PAX5, Bcl6, OCT2, BOB1, MUM1, and Ki67 while CD20 was only focally positive. The underlying PCFCL cells expressed CD20, CD79a, bcl6, and CD10 but interpretation of bcl2 was difficult due to an abundant T-cell background. The proliferative index Ki67 in the PCFCL was estimated at 20\%. PCR and FISH studies did not detect the presence of the $t(14 ; 18)$ translocation [30]. The comparison between these two isolated cases may suggest that the PCFCLs associated with H/RS cells have low-proliferation rates and appear clinically indolent. Different than H/RS cells associated with chronic lymphocytic leukemia/small lymphocytic lymphoma, these PCFCL's H/RS-like cells were not associated with positivity for EBV. Furthermore they do no embrace the same immunophenotype as classical H/RS cells being CD45 positive and expressing a strong B-cell antigen repertoire. A larger number of cases and a longer patient's follow-up are however needed to better characterize these morphologically unusual PCFCLs with transformed H/RS-like cells.

\section{Conclusion}

We presented a rare case of a PCFCL associated with H/RSlike cells. Skin involvement by PCFCLs with associated H/RSlike cells has been only rarely reported and may constitute a diagnostic challenge requiring a comprehensive antibody panel and various molecular techniques as well as careful clinical investigation to exclude a $t(14 ; 18)$ negative classical FL.

\section{Conflicts of Interest}

The authors declare that there are no conflicts of interest regarding the publication of this paper.

\section{References}

[1] Adult Non-Hodgkin Lymphoma Treatment-Health Professional Version 2, $\left(\mathrm{PDQ}^{\circledR}\right)$, National Cancer Institute, 2016, http:// www.cancer.gov/types/lymphoma/hp/adult-nhl-treatment-pdq\# link/_552_toc.

[2] N. L. Harris, S. H. Swerdlow, E. S. Jaffe et al., "Follicular Lymphoma," in WHO Classification of Tumours of Hematopoietic and Lymphoma Tissues, S. H. Swerdlow, E. Campo, N. L. Harris et al., Eds., pp. 158-166, International Agency for Research on Cancer, Lyon, France, 4th edition, 2008.

[3] R. Franco, A. Fernández-Vázquez, M. Mollejo et al., "Cutaneous Presentation of Follicular Lymphomas," Modern Pathology, vol. 14, no. 9, pp. 913-919, 2001.

[4] L. Cerroni, E. Arzberger, B. Pütz et al., "Primary cutaneous follicle center cell lymphoma with follicular growth pattern," Blood, vol. 95, no. 12, pp. 3922-3928, 2000.

[5] E. Leich, I. Salaverria, S. Bea et al., "Follicular lymphomas with and without translocation $t(14 ; 18)$ differ in gene expression profiles and genetic alterations," Blood, vol. 114, no. 4, pp. 826834, 2009.
[6] S. H. Swerdlov, E. Campo, N. L. Harris et al., World Health Organization (WHO) Classification of Tumours of Haematopoietic and Lymphoid Tissues, World Health Organization, Lyon, France, 2008.

[7] S. H. Swerdlow, E. Campo, S. A. Pileri et al., "The 2016 revision of the World Health Organization classification of lymphoid neoplasms," Blood, vol. 127, no. 20, pp. 2375-2390, 2016.

[8] L. Cerroni, M. Volkenandt, E. Rieger, H. Peter Soyer, and H. Kerl, "bcl-2 Protein expression and correlation with the interchromosomal 14; 18 translocation in cutaneous lymphomas and pseudolymphomas," Journal of Investigative Dermatology, vol. 102, no. 2, pp. 231-235, 1994.

[9] L. Cerroni and H. Kerl, "Primary cutaneous follicle center cell lymphoma," Leukemia and Lymphoma, vol. 42, no. 5, pp. 891900, 2001.

[10] E. S. Jaffe, N. L. Harris, J. W. Vardiman, E. Campo, and D. A. Arber, Hematopathology, Elsevier Saunders, Ontario, Canada, 1st edition, 2011.

[11] R. A. Wilcox, "Cutaneous B-cell lymphomas: 2016 update on diagnosis, risk-stratification, and management," American Journal of Hematology, vol. 91, no. 10, pp. 1052-1055, 2016.

[12] J. R. Goodlad, A. S. Krajewski, P. J. Batstone et al., "Primary cutaneous follicular lymphoma: a clinicopathologic and molecular study of 16 cases in support of a distinct entity," American Journal of Surgical Pathology, vol. 26, no. 6, pp. 733-741, 2002.

[13] V. Szablewski, S. Ingen-Housz-Oro, M. Baia, M.-H. DelfauLarue, C. Copie-Bergman, and N. Ortonne, "Primary cutaneous follicle center lymphomas expressing BCL2 protein frequently harbor BCL2 gene break and may present 1p36 deletion," American Journal of Surgical Pathology, vol. 40, no. 1, pp. 127136, 2016.

[14] E.-M. Son and J. Huh, "Reed-Sternberg-like cells in follicular lymphoma," Blood Research, vol. 49, no. 3, p. 147, 2014.

[15] Sung Sik Shin, J. Ben-Ezra, J. S. Burke, K. Sheibani, and H. Rappaport, "Reed-Sternberg-like cells in low-grade lymphomas are transformed neoplastic cells of B-cell lineage," American Journal of Clinical Pathology, vol. 99, no. 6, pp. 658-662, 1993.

[16] L. J. Gardner, J. M. Polski, H. L. Evans et al., "CD30 expression in follicular lymphomas," Archives of Pathology and Laboratory Medicine, vol. 125, pp. 1036-1041, 2001.

[17] M. Piris, K. C. Gatter, and D. Y. Mason, "CD 30 expression in follicular lymphoma," Histopathology, vol. 18, no. 1, pp. 25-29, 1991.

[18] R. Alsabeh, L. J. Medeiros, C. Glackin, and L. M. Weiss, “Transformation of follicular lymphoma into CD30-large cell lymphoma with anaplastic cytologic features," American Journal of Surgical Pathology, vol. 21, no. 5, pp. 528-536, 1997.

[19] A. C. Wotherspoon and R. P. Hasserjian, "Immunophenotyping in the differential diagnosis of histologically low grade B cell lymphomas," Current Diagnostic Pathology, vol. 6, no. 1, pp. 5563, 2000.

[20] R. Sabharwal, S. Sengupta, B. Sharma, and S. Gupta, "Update on Hodgkin's lymphoma," Cinical Cancer Investigation Journal, vol. 2, no. 2, pp. 106-112, 2013.

[21] G. Burg, W. Kempf, A. Cozzio et al., "WHO/EORTC classification of cutaneous lymphomas 2005: histological and molecular aspects," Journal of Cutaneous Pathology, vol. 32, no. 10, pp. 647674, 2005.

[22] J. C. Gomez-Gelvez and L. B. Smith, "Reed-sternberg-like cells in non-Hodgkin lymphomas," Archives of Pathology \& Laboratory Medicine, vol. 139, no. 10, pp. 1205-1210, 2015. 
[23] M. G. Bayerl, G. Bentley, C. Bellan, L. Leoncini, W. C. Ehmann, and M. Palutke, "Lacunar and reed-sternberg-like cells in follicular lymphomas are clonally related to the centrocytic and centroblastic cells as demonstrated by laser capture microdissection," American Journal of Clinical Pathology, vol. 122, no. 6, pp. 858-864, 2004.

[24] N. Mackrides, G. Campuzano-Zuluaga, Y. Maque-Acosta et al., "Epstein-Barr virus-positive follicular lymphoma," Modern Pathology, vol. 30, no. 4, pp. 519-529, 2017.

[25] M. Yoshida, A. Ichikawa, H. Miyoshi et al., "High frequency of $t(14 ; 18)$ in Hodgkin's lymphoma associated with follicular lymphoma," Pathology International, vol. 62, no. 8, pp. 518-524, 2012.

[26] T. Marafioti, M. Hummel, H.-D. Foss et al., "Hodgkin and ReedSternberg cells represent an expansion of a single clone originating from a germinal center B-cell with functional immunoglobulin gene rearrangements but defective immunoglobulin transcription," Blood, vol. 95, no. 4, pp. 1443-1450, 2000.

[27] R. Küppers, A. B. Sousa, A. S. Baur, J. G. Strickler, K. Rajewsky, and M.-L. Hansmann, "Common germinal-center B-cell origin of the malignant cells in two composite lymphomas, involving classical hodgkin's disease and either follicular lymphoma or BCLL," Molecular Medicine, vol. 7, no. 5, pp. 285-292, 2001.

[28] L. C. Lawnicki, D. D. Weisenburger, P. Aoun, W. C. Chan, R. S. Wickert, and T. C. Greiner, "The $t(14 ; 18)$ and bcl-2 expression are present in a subset of primary cutaneous follicular lymphoma: association with lower grade," American Journal of Clinical Pathology, vol. 118, no. 5, pp. 765-772, 2002.

[29] D. A. Arber, "Molecular diagnostic approach to Non-Hodgkins Lymphoma," The Journal of Molecular Diagnostics, vol. 2, no. 4, pp. 178-190, 2000.

[30] M. Dilly, H. Ben-Rejeb, B. Vergier et al., "Primary cutaneous follicle center lymphoma with Hodgkin and Reed-Sternberglike cells: a new histopathologic variant," Journal of Cutaneous Pathology, vol. 41, no. 10, pp. 797-801, 2014. 


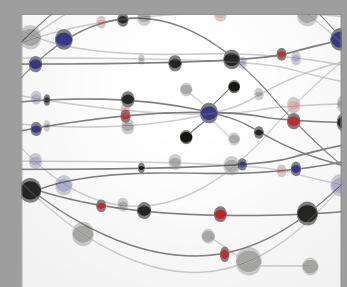

The Scientific World Journal
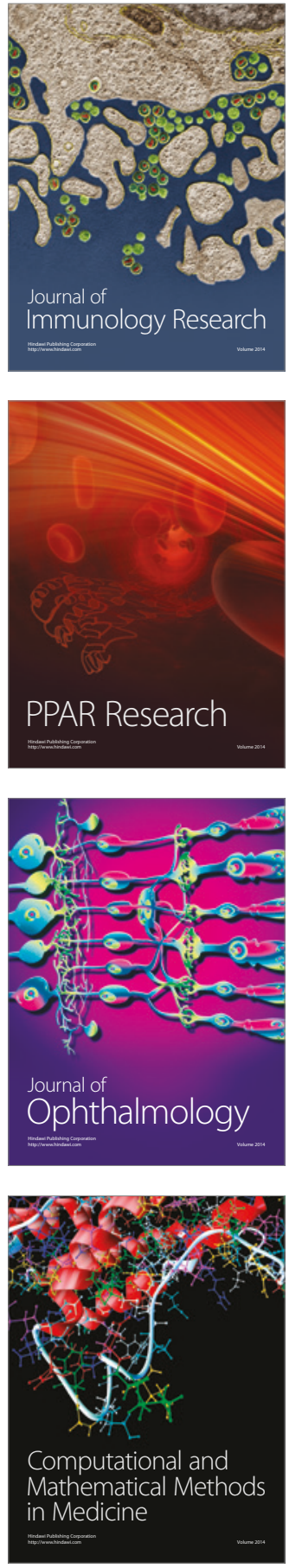

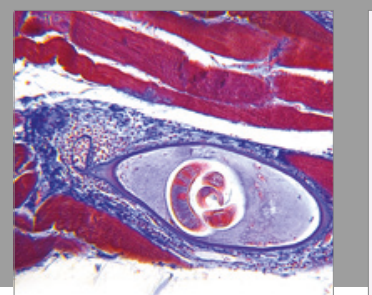

Gastroenterology Research and Practice
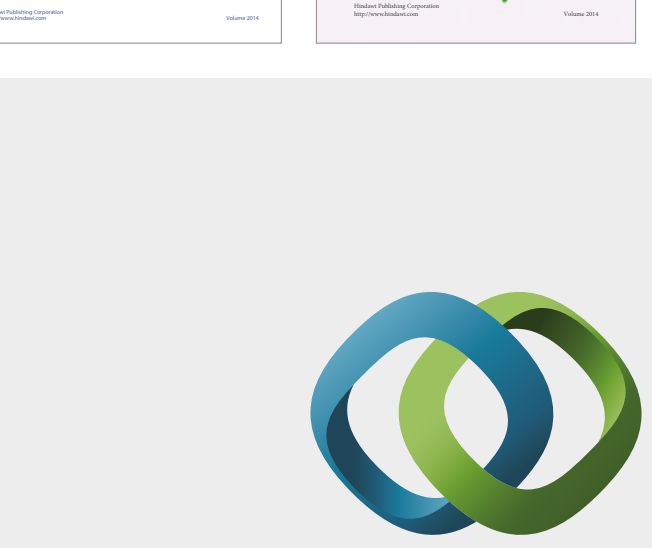

\section{Hindawi}

Submit your manuscripts at

https://www.hindawi.com
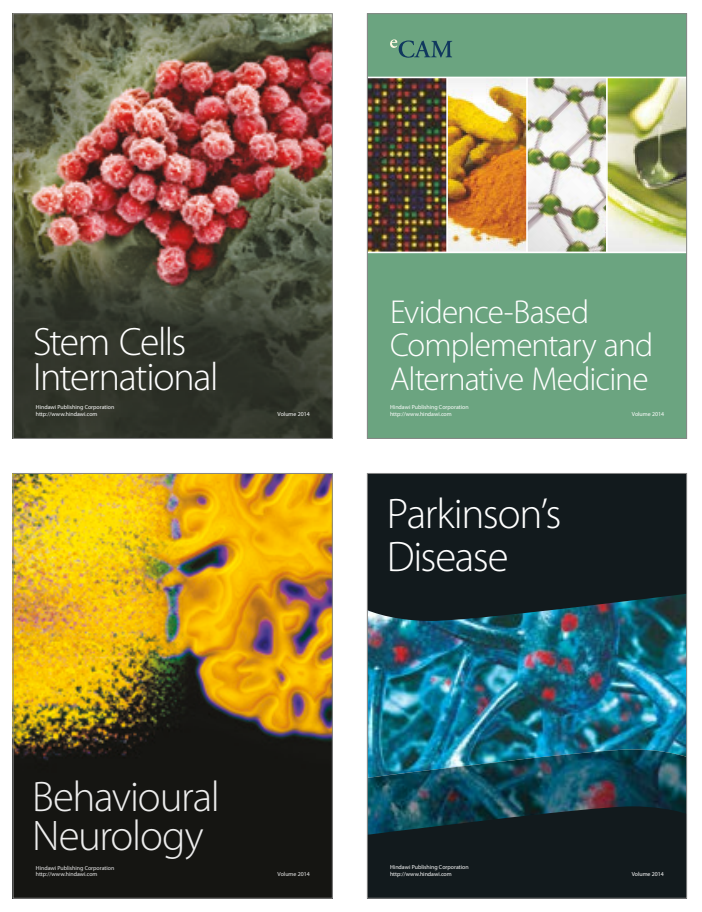
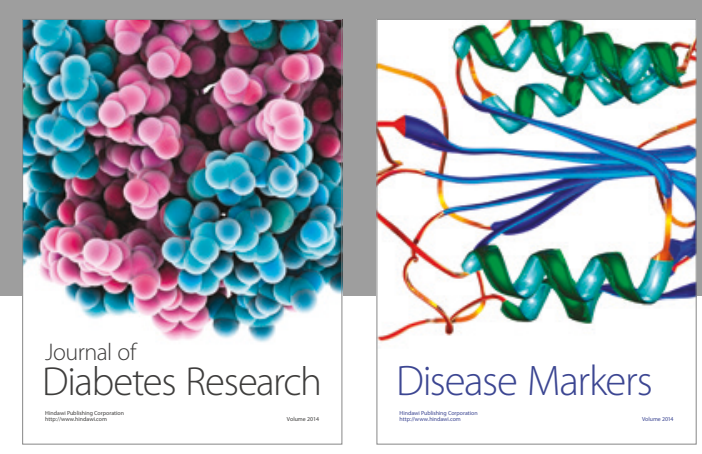

Disease Markers
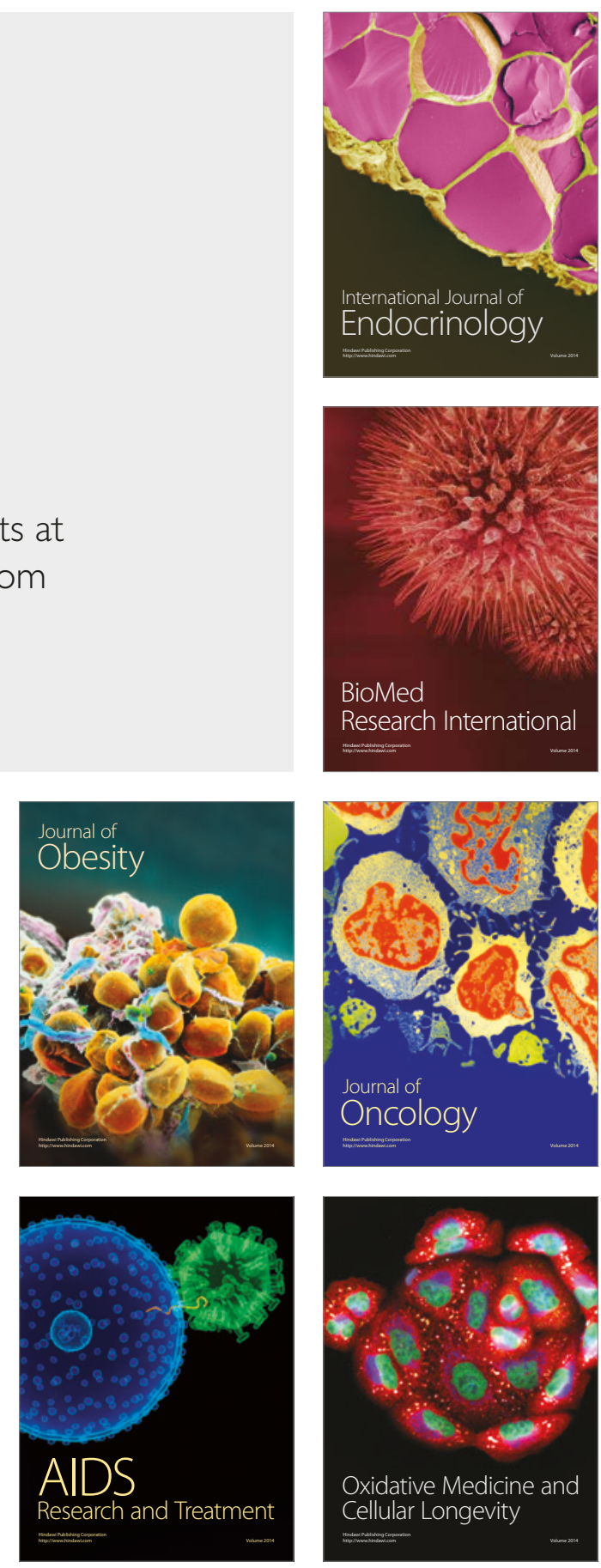